\title{
MULTI-DRUG RESISTANCE AND BIOFILM PRODUCTION AMONG DIARRHEAGENIC ESCHERICHIA COLI PATHOTYPES ISOLATED FROM STOOLS OF CHILDREN WITH ACUTE DIARRHEAL DISEASE
}

\author{
E.E. David ${ }^{a}$, M.A. Yameen ${ }^{b}$, I. Igwenyi ${ }^{c}$, A.C. Okafor ${ }^{d}$, U.N. Obeten ${ }^{a}$, D.O. Obasi ${ }^{a}$, \\ U.R. Ezeiloa ${ }^{a}$ M.N. Emeribole ${ }^{a}$, Ch.N. David ${ }^{c}$ \\ ${ }^{a}$ Alex Ekwueme Federal University Ndufu-Alike, Ikwo, Ebonyi State, Nigeria \\ ${ }^{b}$ COMSATS University Islamabad, Abbottabad Campus, Abbottabad, Pakistan \\ ${ }^{c}$ Ebonyi State University, Ebonyi State, Nigeria \\ ${ }^{d}$ Edo University, Iyamho, Edo State, Nigeria
}

\begin{abstract}
Background. Diarrheagenic E. coli (DEC) is an etiological agent of childhood diarrhea. Resistance against commonly used drugs in the empirical treatment of enteric infections has increased among DEC. Relationship between antibiotic resistance and biofilm formation in microorganisms have been widely reported. This study was aimed to determine the antibiotic resistance and biofilm production pattern among DEC pathotypes isolated from stools of children aged 0-5 years with acute diarrheal disease in Abakaliki, Nigeria. Materials and methods. Diarrheal stool samples were obtained from 60 children and $E$. coli were isolated and identified using standard guidelines provided for laboratory diagnosis of enteric pathogens. Molecular identification was done by amplification of $E$. coli universal stress protein A (uspA) using polymerase chain reaction (PCR) method. Detection of virulent genes of DEC pathotypes was performed in a group of multiplex PCR using their specific primers. Kirby-Bauer disk diffusion method was used to determine the antibiotic susceptibility patterns of the isolates while biofilms production was detected by thiazolyl blue tetrazolium bromide dye in a 96-well plate. Results. DEC was isolated in 40 stools among which EIEC [40\% $(\mathrm{n}=16)]$ was commonly detected followed by ETEC [30\% $(n=12)]$, EAEC [20\% $(n=8)]$ and typical EPEC [10\% $(n=4)]$. Half of EAEC showed the highest multidrug resistance against ampicillin, cefoxitin, ciprofloxacin, levofloxacin, and tetracycline with the strongest biofilm production followed by all the EPEC which were resistant to ampicillin, ciprofloxacin, levofloxacin, and tetracycline with moderate biofilm production. All the LT-ETEC exhibited the least resistance to ampicillin and tetracycline with the weakest biofilm production. Conclusion. High frequency of the EIEC pathotype suggests its role as the primary etiological agent of diarrhea in children. Correlation between high drug resistance and biofilm production among the pathotype may indicate that biofilms may provide compatible uptake of resistance genes.
\end{abstract}

Key words: diarrheagenic E. coli (DEC), antibiotic resistance, diarrheal stool, multiplex PCR, multi-drug resistance, polymerase chain reaction, biofilms.

\author{
Адрес для переписки: \\ Эбука Элайджа Давид \\ 1010, Нигерия, штат Эбони, Абакалики, \\ Федеральный университет Алекса Эквуэме. \\ Тел.: +234 803 318-88-23. \\ E-mail: david.ebuka@funai.edu.ng
}

\author{
Contacts: \\ Ebuka Elijah David \\ 1010, Nigeria, Ebonyi State, \\ Abakaliki, Alex Ekwueme Federal University. \\ Phone: +234 803 318-88-23. \\ E-mail: david.ebuka@funai.edu.ng
}

\section{Citation:}

David E.E., Yameen M.A., Igwenyi I., Okafor A.C., Obeten U.N., Obasi D.O., Ezeilo U.R., Emeribole M.N., David Ch.N. Multi-drug resistance and biofilm production among diarrheagenic Escherichia coli pathotypes isolated from stools of children with acute diarrheal disease // Russian Journal of Infection and Immunity = Infektsiya i immunitet, 2021, vol. 11, no. 5, pp. 958-964. doi: 10.15789/2220-7619-MDR-1589

\section{Для цитирования: Эзейло У.Р., Эмериболе М.Н., Дэвид Ч.Н. Множественная лекарственная устойчивость и образование биопленок среди диарейных патотипов Escherichia coli, выделенных из стула детей с острой диареей // Инфекция и иммунитет. 2021. Т. 11, № 5. С. 958-964. doi: 10.15789/2220- 7619-MDR-1589}

(c) David E.E. et al., 2021 


\title{
МНОЖЕСТВЕННАЯ ЛЕКАРСТВЕННАЯ УСТОЙЧИВОСТЬ И ОБРАЗОВАНИЕ БИОПЛЕНОК СРЕДИ ДИАРЕЙНЫХ ПАТОТИПОВ ЕSCHЕRІCHІА COLI, ВЫДЕЛЕННЫХ ИЗ СТУЛА ДЕТЕЙ С ОСТРОЙ ДИАРЕЕЙ
}

\author{
Дэвид Э.Э., ${ }^{1}$, Ямин М.А. ${ }^{2}$, Игвени И. ${ }^{3}$, Окафор А.С. ${ }^{4}$, Обетен У.Н. ${ }^{1}$, Обаси Д.О. ${ }^{1}$, Эзейло У.Р. \\ Эмериболе М.Н. ${ }^{1}$, Дэвид Ч.Н. ${ }^{3}$ \\ ${ }^{1}$ Федеральный университет Алекса Эквуэме «Ндуфу Алик Икво», Икво, штат Эбони, Нигерия \\ ${ }^{2}$ Университет COMSATS в Исламабаде, г. Абботтабад, Пакистан \\ ${ }^{3}$ Государственный университет Эбони, штат Эбони, Нигерия \\ ${ }^{4}$ Университет Эдо, г. Иямхо, штат Эдо, Нигерия
}

Резюме. Актуальность. Диареагенная кишечная палочка (DEC) является этиологическим агентом диареи у детей. Устойчивость клекарствам, обычно используемым при эмпирическом лечении кишечных инфекций, среди DEC увеличилась. Широко известна взаимосвязь между устойчивостью к антибиотикам и образованием биопленок у микроорганизмов. Настоящее исследование было направлено на определение устойчивости к антибиотикам и характера биопленкообразования среди патотипов DEC, выделенных из стула детей в возрасте 0-5 лет с острой диареей в Абакалики, Нигерия. Материалы и методы. Образцы стула были получены от 60 детей, и с использованием стандартных подходов, предусмотренных для лабораторной диагностики кишечных патогенов, были выделены и идентифицированы E. coli. Молекулярную идентификацию проводили путем амплификации участка гена универсального стрессового белка А (uspA) E. coli с использованием метода полимеразной цепной реакции (ПЦР). Выявление вирулентных генов патотипов DEC проводили с применением мультиплексной ПЦР со специфическими праймерами. Метод дисковой диффузии Кирби-Бауэра был использован для определения характеристик чувствительности изолятов к антибиотикам, в то время как образование биопленок определяли с помощью красителя тиазолила синего тетразолия бромида в 96-луночном планшете. Результаты. DEC была выделена в 40 образцах. Наиболее часто выявлялась энтероинвазивная $E$. coli (EIEC) [40\% (n = 16)], затем энтеротоксигенная E. coli (ETEC) [30\% $(\mathrm{n}=12)]$, энтероагрегативная к E. coli (EAEC) [20\% (n =8)] и типичная энтеропатогенная E. coli $(\mathrm{EPEC})[10 \%(\mathrm{n}=4)]$. Половина штаммов ЕАЕС обнаружила самую высокую множественную лекарственную устойчивость к ампициллину, цефокситину, ципрофлоксацину, левофлоксацину и тетрациклину с самым сильным образованием биопленок. Далее по степени устойчивости к антибиотикам и уровню образования биопленок следовали ЕРЕС, которые были устойчивы к ампициллину, ципрофлоксацину, левофлоксацину и тетрациклину и характеризовались умеренным биопленкобразованием. ETEC с термолабильным токсином LT-ETEC проявляли наименьшую устойчивость к ампициллину и тетрациклину с наименьшим образованием биопленок. Заключение. Высокая частота патотипа ЕІЕС свидетельствует о его роли в качестве основного этиологического агента диареи у детей. Корреляция между высокой лекарственной устойчивостью и производством биопленок среди патотипов может указывать на то, что биопленки могут обеспечивать оптимальный уровень захвата генов устойчивости.

Ключевые слова: диареагенная кишечная палочка (DEC), устойчивость к антибиотикам, диарейный стул, мультиплексная ПЦР, множественная лекарственная устойчивость, полимеразной цепная реакция, биопленки.

\section{Introduction}

Diarrhea is characterized by the passage of watery stools at least two-three times in a $24 \mathrm{~h}$ period as a result of gastrointestinal infection majorly caused by a variety of bacterial, viral and parasitic pathogens. Among children less than five years, Nigeria accounts for $11 \%$ of $50 \%$ global mortalities estimated at 150,000 yearly, with a prevalence rate of $18.8 \%$ [2, 18]. Intestinal pathogenic $E$. coli strains also known as diarrheagenic $E$. coli (DEC) is a major etiological agent of pediatric diarrhea [36]. DEC can be transmitted via the fecal-oral route by ingesting food or water contaminated by human or animal feces [1, 11]. Infection with DEC causes an alteration of the movement of ions and water in the gastrointestinal tract by altering the balance between fluid-electrolyte absorption and secretion leading to diarrhea [34]. DEC is divided into enteropathogenic E. coli (EPEC), enterotoxigenic E. coli (ETEC), enterohemorrhagic E. coli (EHEC), enteroinvasive $E$. coli
(EIEC), enteroaggregative E. coli (EAEC) and diffusely adherent $E$. coli (DAEC). The divisions of DEC into groups are based on their specific virulence factors and phenotypic traits. Each pathological type has characteristic virulence determinants that contribute to its pathogenic mechanisms [32]. The prevalence and other epidemiological features of DEC types in childhood diarrhea vary with geographical area. Resistance against the commonly used drugs for the treatment of enteric infections including ampicillin, tetracycline, and co-trimoxazole has increased among DEC [14], which have led to the use of higher antimicrobials like fluoroquinolones as alternatives. E. coli strains form surface communities of biofilm structure that contributes to resistance to different antimicrobial agents and to its pathogenicity. Critical for the formation of biofilm on abiotic material such as food or food-contact surfaces, $E$. coli possess adhesins important for the formation of secreted $\operatorname{IgA}$ mediated biofilm within the gut [5]. 
While the frequency of DEC and its multi-drug resistance in childhood diarrhea have been reported in some parts of Nigeria [11, 12], the correlation between multi-drug resistance and biofilms production among DEC is still lacking. In other parts of the world, relationship amongst antibiotics resistance, distribution of virulence factors and biofilm formation in $E$. coli have been widely reported [6, 9, 13, 28] but scarcely for DEC. Hence, this study was aimed to determine the antibiotic resistance and biofilm production patterns among DEC pathotypes isolated from stools of children aged $0-5$ years with acute diarrheal disease.

\section{Materials and methods}

Isolation and identification of diarrheagenic E. coli (DEC). Sixty (60) fecal samples were collected from children with incidence of diarrhea under the age of five (5) years at Alex Ekwueme Federal Teaching Hospital, Abakaliki, Nigeria (AE-FETHA). Ethical clearance was obtained from Ethical and Research Committee of the hospital, after which informed consent was obtained from the parents of the children. Fecal samples were processed as described in the standard guidelines provided for laboratory diagnosis of enteric pathogens [7]. E. coli was isolated with Eosin Methylene Blue, EMB (a selective media for $E$. coli) and identified with biochemical tests like Indole test, Methyl red test, Voges-Proskauer (VP) test, Citrate utilization test and Eijkman test.

Following extraction of $E$. coli genomic DNA as previously described by Healey and colleagues [30], $E$. coli isolates were further identified using primers derived from the DNA sequences flanking the gene encoding the universal stress protein A (uspA); EC1: 5'-CCGATACGCTGCCAATCAGT-3': EC2:5'-ACG CAGACCGTAAGGGCCAGAT-3' [16, 21]. PCR was performed in a total reaction volume of $25 \mu \mathrm{L}$ with $12.5 \mu \mathrm{L}$ GoTaq Green master mix, $9.0 \mu \mathrm{L}$ nuclease free water (Promega, USA), $0.5 \mu \mathrm{L}$ of forward and reverse primers each and $2.5 \mu \mathrm{L}$ of template. Optimization were done at the following conditions: $94^{\circ} \mathrm{C}$ for $5 \mathrm{~min}$, initial template denaturation, 25 cycles at $94^{\circ} \mathrm{C}$ for $30 \mathrm{~s}$, final denaturation, $50^{\circ} \mathrm{C}$ for $1 \mathrm{~min}$, annealing, $72^{\circ} \mathrm{C}$ for $1 \mathrm{~min} 30 \mathrm{~s}$, extension and $72^{\circ} \mathrm{C} 7 \mathrm{~min}$, final extension. About $884 \mathrm{bp}$ PCR products were analyzed by Gel electrophoresis in $1 \%$ agarose gel in TBE buffer at $100 \mathrm{~V}$. The gels were stained with ethidium bromide and photographed under ultraviolet light using a gel documentation system (Fig. S1 in supplementary file).

Detection of virulent genes of DEC pathotypes. Detection of virulent genes of diarrheagenic $E$. coli (DEC) were performed in a group of multiplex PCR using their specific primers as previously described by [23]. All the primers and their corresponding virulent genes are shown in Table S1 (see supplementary file). The thermo cycling conditions were pro- grammed using Applied Biosystem, 2720 Thermal Cycler, USA in $25 \mu \mathrm{L}$ reaction mixture as follows: initial denaturation for $5 \mathrm{~min}$ at $94^{\circ} \mathrm{C}$, denaturation at $94^{\circ} \mathrm{C}$ for $30 \mathrm{~s}, 72^{\circ} \mathrm{C}$ for $1 \mathrm{~min} 30 \mathrm{~s}$ extensions for 25 cycles with final extension of $5 \mathrm{~min}$ at $72^{\circ} \mathrm{C}$. PCR products were analyzed by Gel electrophoresis in $1 \%$ agarose gel in TBE buffer at $100 \mathrm{~V}$. The gels were stained with ethidium bromide and photographed under ultraviolet light using a gel documentation system (Fig. S2 in supplementary file).

Antibiotic susceptibility testing. Antimicrobial susceptibility testing was performed by the Disk Diffusion Method according to the Clinical and Laboratory Standards Institute guidelines, CLSI [10]. Antimicrobial agents tested were tetracycline $(30 \mu \mathrm{g})$, ampicillin $(10 \mu \mathrm{g})$, amoxicillin/clavulinic acid $(5 \mu \mathrm{g})$, imipenem $(10 \mu \mathrm{g})$, ciprofloxacin $(5 \mu \mathrm{g})$ and levofloxacin (5 $\mu \mathrm{g}$ ) (Oxoid Ltd, Basingstoke, Hamphire, England). The multi-drug resistance criteria adopted was defined as earlier published [19].

Biofilm formation. Formation of biofilms by DEC was evaluated using a method described by [24] with slight modifications. About $200 \mu \mathrm{L}$ of E. coli broth culture was prepared with glucose. The broth was added to 96 -well plates and incubated for $24 \mathrm{~h}$ at $37^{\circ} \mathrm{C}$ to allow cell attachment and biofilm formation. The supernatant fluid in each well was aspirated and washed with $0.1 \mathrm{M}$ phosphate buffer saline (PBS). The wells were stained with $100 \mu \mathrm{L}$ of thiazoylblue tetrazolium bromide for $2 \mathrm{~h}$ at $37^{\circ} \mathrm{C}$, the staining solutions were aspirated and the wells washed with PBS. About $200 \mu \mathrm{L}$ DMSO were added to the wells and the amount of stain in each well was determined at $570 \mathrm{~nm}$ using micro plate reader (FLUOstar Omega, BMG LABTECH, Germany). Wells containing only $100 \mu \mathrm{L}$ sterile broth were used as control. Its optical density reading was used as back ground value which was subtracted from the other test values. The method earlier described by Pavlickova et al. [28] was used to group the organisms as weak, moderate and strong biofilm producers.

\section{Results}

A total of 60 stool samples from diarrheal children $(n=60)$ were collected for this study, of which $67 \%(n=40)$ were positive for one or more pathotype of DEC. Virulent eltA gene for ST-ETEC was detected in $20 \%(n=8)$ of the isoates while $10 \%(n=4)$ expressed eltB for LT-ETEC. Twenty percent (20\%) $(n=8)$ also expressed pCVD (the nucleotide sequence of EcoR1-Pst1 DNA fragment of pCVD432) gene for EAEC while $40 \%(\mathrm{n}=16)$ expressed ial gene (invasion-associated locus of the invasive plasmid found in EIEC). Ten percent $(10 \%)(\mathrm{n}=4)$ expressed $e a e A$ gene (a structural gene for intimin) and $b f p A$ gene (a structural gene for the bundle-forming pilus) found in typical EPEC (Fig.).

The isolates phenotypically exhibited high resistance for tetracycline [36 (90\%)] followed by ampi- 
cillin [32 (80\%)], ciprofloxacin and levofloxacin [20 $(50 \%)]$, cefoxitin [4 (10\%)] and amoxicillin-clav and imipenem [0 (0\%)]. Intermediate resistance was seen in amoxicillin-clav [28 (70\%)] followed by ampicillin, cefoxitin, tetracycline [4 (10\%)] and imipenem, ciprofloxacin, levofloxacin $[0(0 \%)]$. The highest sensitivity was seen in imipinem [40 (100\%)] followed by cefoxitin [32 (80\%)], ciprofloxacin and levofloxacin [20 (50\%)], amoxicillin-clav [12 (30\%)], ampicillin $[4(10 \%)]$ and tetracycline $[0(0 \%)]$ (Table 1).

Fifty percent $(50 \%)$ isolates of ST-ETEC were resistant to ampicillin, ciprofloxacin and levofloxacin while $100 \%$ were resistant to tetracycline. All the LT-ETEC exhibited resistance to ampicillin and tetracycline. Fifty percent $(50 \%)$ resistance were seen in EAEC against ampicilin, cefoxitin, ciprofloxacin, levofloxacin and tetracycline. In EIEC, all the isolates were resistant to ampicillin, $50 \%$ were resistant to both ciprofloxacin and levofloxacin while $75 \%$ were resistant to tetracycline. All EPEC were resistant to ampicillin, ciprofloxacin, levofloxacin and tetracycline. Multi-drug resistance were seen in more than $50 \%$ of all the pathotypes except LT-ETEC (Table 2).

From Table 3, the level of biofilm production varies across the pathotypes. While $50 \%$ of the isolates were moderate biofilm producers, $40 \%$ and $10 \%$ exhibited weak and strong production respectively. In ETEC, all the LT-ETEC was weak producers while $50 \%$ were both moderate and weak producers for STETEC. Half of the EAEC isolates showed both strong and weak biofilm production while all the EPEC isolates were moderate in their production of biofilm. Seventy-five and twenty-five percent of EIEC were moderate and weak producers respectively.

\section{Discussion and conclusion}

In this study, the frequency of EIEC [40\% $(n=16)]$ was most common among DEC isolates, followed by ETEC $[30 \%(n=12)]$. This high frequency suggests their role as most common cause of acute childhood diarrhea in this region. In contrast to high EIEC frequency recorded in this study, low frequency (1.2\%) of EIEC was seen in the study carried out in south west Nigeria by Okeke et al. [25], in India (1.8\%) [8] and Ecuador (3.2\%) [37], these suggest that EIEC may play less important role in childhood diarrhea in developing countries. The high ETEC frequency from this study

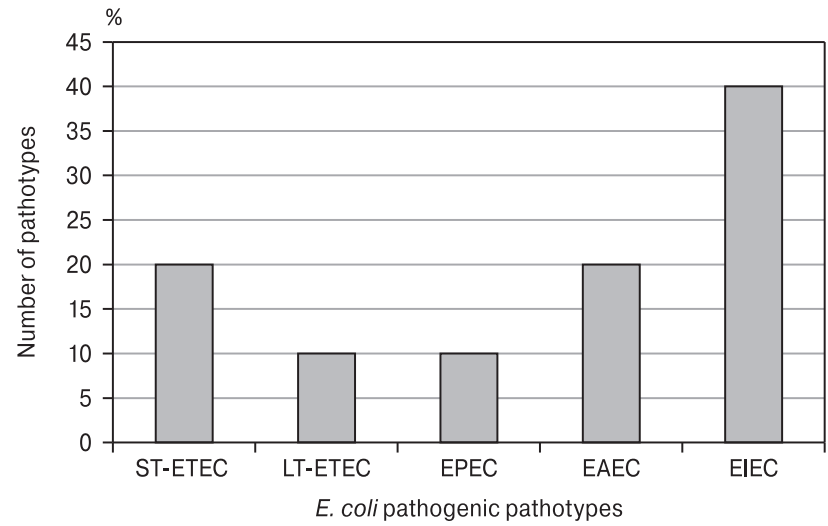

Figure. Distribution of DEC pathotypes

agreed with the one recorded in Onitsha, South East Nigeria where $21.57 \%$ ETEC were detected among DEC isolates [24]. Similar high ETEC frequency of $36.3 \%$ was recorded amongst hospitalized diarrheal children in Kolkata India [15]. In contrast, the frequency of ETEC obtained among DEC isolated from stools of infants and children in Federal Capital Territory, Abuja, Nigeria, was 4\% [17]. The same low frequency was seen in other developing countries; Dar es Salaam, Tanzania (3.6\%) [22]; Western Iran (17.5\%) [3]; Hanoi, Vietnam (2.2\%) [23]. EIEC infection is characterized by the ability of bacteria to invade the human colonic mucosa, conferred by the expression of chromosomal and plasmid-borne genes. Clinical human ETEC isolates produce enterotoxins; the heat stable toxins (ST) and heat labile toxin (LT) and may produce one or more of several colonization factors (CFs) which mediate adherence to the small intestinal mucosa [31].

Table 1. Antibiogram of DEC isolates $(n=40)$

\begin{tabular}{|l|c|c|c|}
\hline Antimicrobials & Resistant & Intermediate & Sensitivity \\
\hline AMP & $32(80 \%)$ & $4(10 \%)$ & $4(10 \%)$ \\
\hline AMC & $0(0 \%)$ & $28(70 \%)$ & $12(30 \%)$ \\
\hline FOX & $4(10 \%)$ & $4(10 \%)$ & $32(80 \%)$ \\
\hline IMP & $0(0 \%)$ & $0(0 \%)$ & $40(100 \%)$ \\
\hline CIP & $20(50 \%)$ & $0(0 \%)$ & $20(50 \%)$ \\
\hline LEV & $20(50 \%)$ & $0(0 \%)$ & $20(50 \%)$ \\
\hline TET & $36(90 \%)$ & $4(10 \%)$ & $0(0 \%)$ \\
\hline
\end{tabular}

Note. AMP - ampicillin, AMC - amoxicillin - clavulinic acid,

FOX - cefoxitin, IMP - imipenem, CIP - ciprofloxacin,

LEV - levoflxacin, TET - tetracycline.

Table 2. Relationship between DEC pathotypes and antimicrobial resistance

\begin{tabular}{|l|c|c|c|c|c|c|c|c|}
\hline & $\mathbf{n}$ & AMP & AMC & FOX & CIP & LEV & IMP & TET \\
\hline ST-ETEC & 8 & $50 \%(4)$ & $0 \%(0)$ & $0 \%(0)$ & $50 \%(4)$ & $50 \%(4)$ & $0 \%(0)$ & $100 \%(8)$ \\
\hline LT-ETEC & 4 & $100 \%(4)$ & $0 \%(0)$ & $0 \%(0)$ & $0 \%(0)$ & $0 \%(0)$ & $0 \%(0)$ & $100 \%(4)$ \\
\hline EAEC & 8 & $50 \%(4)$ & $0 \%(0)$ & $50 \%(4)$ & $50 \%(4)$ & $50 \%(4)$ & $0 \%(0)$ & $100 \%(8)$ \\
\hline EIEC & 16 & $100 \%(16)$ & $0 \%(0)$ & $0 \%(0)$ & $50 \%(16)$ & $50 \%(16)$ & $0 \%(0)$ & $75 \%(12)$ \\
\hline EPEC & 4 & $100 \%(4)$ & $0 \%(0)$ & $0 \%(0)$ & $100 \%(4)$ & $100 \%(4)$ & $0 \%(0)$ & $100 \%(4)$ \\
\hline
\end{tabular}

Note. AMP - ampicillin, AMC - amoxicillin - clavulinic acid, FOX - cefoxitin, IMP - imipenem, CIP - ciprofloxacin, LEV - levoflxacin, TET - tetracycline. 
Table 3. Level of biofilm formation in DEC isolates

\begin{tabular}{|l|c|c|c|}
\hline & Strong & Moderate & Weak \\
\hline ST-ETEC & $0(0 \%)$ & $4(50 \%)$ & $4(50 \%)$ \\
\hline LT-ETEC & $0(0 \%)$ & $0(0 \%)$ & $4(100 \%)$ \\
\hline EAEC & $4(50 \%)$ & $0(0 \%)$ & $4(50)$ \\
\hline EIEC & $0(0 \%)$ & $12(75 \%)$ & $4(25 \%)$ \\
\hline EPEC & $0(0 \%)$ & $4(100 \%)$ & $0(0 \%)$ \\
\hline Total & $4(10 \%)$ & $20(50 \%)$ & $16(40 \%)$ \\
\hline
\end{tabular}

In this study, EAEC [20\% $(n=8)]$ ranked second to Typical EPEC $[10 \%(n=4)]$ as the least frequent DEC. When compared to results obtained from other regions, it becomes evident that the prevalence and other epidemiological features of DEC types in childhood diarrhea vary with geographical area [29]. In agreement with our result, EPEC was the least prevalent in Ecuador (0.9\%) [37], India 4.79\% [8] and Egypt (5.2\%) [4]. Different from the result of this study, EAEC was recorded as the most prevalent in Kolkata India (48.2\%) [15], Southwest Nigeria (10.3\%) [25] and $34.4 \%$ in Gwagwalada, Abuja, Nigeria [27].

The DEC isolates were most resistance to tetracycline [36 (90\%)] followed by ampicillin [32 (80\%)], ciprofloxacin/levofloxacin [20 (50\%)] and cefoxitin $[4(10 \%)]$. More than $50 \%$ of all the DEC was multi-drug resistant with EAEC showing resistant to 5 different antibiotics. A similar result was also seen in a previous study where most of the DEC isolates $(67.5 \%)$ were resistant to ampicillin and tetracycline [3]. Such multidrug resistance among DEC isolates against classical antibiotics like ampicillin and tetracycline was also recorded in Bolivia [31]. Much of the reasons for these high rates of resistance are related to the fact that, antibiotics, despite not being required for the treatment of acute diarrhea, are widely prescribed for these forms of infections [26].

From this study, $50 \%$ of the DEC isolates were moderate biofilm producers, while $40 \%$ and $10 \%$ exhibited weak and strong production respectively. Isolates that exhibited strong biofilm production correlates with $50 \%$ EAEC with the highest multidrug resistance. Relationship between antimicrobial resistance and biofilm formation among isolates of Gramnegative bacteria species including $E$. coli have been reported [6]. Biofilms are bacterial population firmly crammed by extra-cellular matrix which possesses bacterial secreted polymers such as exopolysaccharides, extracellular DNA, proteins and amyloidogenic proteins. Microbial cells within biofilms have shown 1000 times more antibiotics resistance than the planktonic cells [33]. The antibiotics resistance mechanism of biofilms communities commonly involves the uptake of resistance genes by horizontal gene transfer. Biofilms provides compatible conditions for this horizontal gene transfer which include high cell density, increased genetic competence and accumulation of genetic elements or uptake of resistance genes. Conjugation is the only mechanism of horizontal transfer of resistant genes in biofilms and may confirm the resistance to several antibiotics [20]. This suggests that increased biofilms seen in EAEC isolates increased the chances of horizontal antibiotics resistant gene transfer which may be acquired from other sources. This point to the need to apply a One Health approach and study environmental reservoirs more closely, rather than focusing only on the resistance that arises following antimicrobial administration [35].

We observed the presence of four different DEC pathotypes with EIEC and ETEC most commonly encountered. High frequency of EIEC in this region suggests that it is one of the most common causes of diarrhea in children $0-5$ years. Most of these DEC isolates are resistant to more than one antimicrobial agent which suggests continued use and misuse of these drugs. Therefore it is important to continue the surveillance of antimicrobial resistance of enteric bacterial pathogens for effective control of childhood diarrheal diseases. The number of drug resistance increased with the strength of biofilm production among the DEC pathotypes. This may suggest that biofilms may provide compatible uptake of resistance genes.

\section{Supplementary files}

Supplementary materials are available at: http://dx.doi.org/10.15789/2220-7619-MDR-1589

\section{Acknowledgement}

The World Academy of Sciences (TWAS) in collaboration with Higher Education Commission (HEC), Pakistan through COMSATS University Islamabad, Abbottabad Campus, Abbottabad, Pakistan provided funding for this work. The funding body had no role in either the design of the study, collection of samples, analysis, and interpretation of data or in writing of the script.

\section{Competing interests}

No competing interests are declared by authors.

\section{References}

1. Adefisoye M.A., Okoh A.I. Identification and antimicrobial resistance prevalence of pathogenic Escherichia coli strains from treated wastewater effluents in Eastern Cape, South Africa. Microbiologyopen., 2016, vol. 5, pp. 143-151. doi: 10.1002/mbo3.319

2. Akinrotoye K.P., Uzal U. Combating diarrhoea in Nigeria: the way forward. J. Microbiol. Exp., 2018, vol. 6, no. 4, pp. $191-197$. doi: 10.15406/jmen.2018.06.00213

3. Alikhani M.Y., Hashemi S.H., Aslani M.M., Farajnia S. Prevalence and antibiotic resistance patterns of diarrheagenic Escherichia coli isolated from adolescents and adults in Hamedan, Western Iran. Iran J. Microbiol., 2013, vol. 5, no. 1, pp. 42-47. 
4. Behiry I.K., Abada E.A., Ahmed E.A., Labeeb R.S. Enteropathogenic Escherichia coli associated with diarrhea in children in Cairo, Egypt. Sci. World J., 2011, vol. 11, pp. 2613-2619. doi: 10.1100/2011/485381

5. Bollinger R.R., Everett M.L., Wahl S.D., Lee Y.H., Orndorff P.E., Parker W. Secretory IgA and mucin-mediated biofilm formation by environmental strains of Escherichia coli: role of type 1 pili. Mol. Immunol., 2006, vol. 43, no. 4, pp. 378-387. doi: 10.1016/ j.molimm.2005.02.013

6. Cepas V., López Y., Muñoz E., Rolo D., Ardanuy C., Martí S., Xercavins M., Horcajada J.P., Bosch J., Soto S.M. Relationship between biofilm formation and antimicrobial resistance in gram-negative bacteria. Microb. Drug Resist., 2019, vol. 25, no. 1, pp. 72-79. doi: $10.1089 / \mathrm{mdr} .2018 .0027$

7. Cheesbrough M. District laboratory practice in tropical countries. Part 2 (2 ${ }^{\text {nd }}$ ed.). Cambridge: Cambridge University Press, 2006. doi: 10.1017/CBO9780511543470

8. Chellapandi K., Dutta T.K., Sharma I., De Mandal S., Kumar N.S., Ralte L. Prevalence of multi drug resistant enteropathogenic and enteroinvasive Escherichia coli isolated from children with and without diarrhea in Northeast Indian population. Ann. Clin. Microbiol. Antimicrob., 2017, vol. 16, no. 1: 49. doi: 10.1186/s12941-017-0225-x

9. Chen D., Zhao T., Doyle M.P. Single- and mixed-species biofilm formation by Escherichia coli O157:H7 and Salmonella, and their sensitivity to levulinic acid plus sodium dodecyl sulfate. Food Control, 2015, vol. 57, pp. 48-53. doi: 10.1016/j.foodcont.2015.04.006

10. CLSI. Performance standards for antimicrobial disk susceptibility tests. $13^{\text {th }}$ ed. CLSI standard M02. Wayne, PA: Clinical and Laboratory Standard Institute, 2018. 13 p.

11. David E.E., Udedi S.C., Ekwealor K.E., Igwilo I.O., Enemali M.O., Ifemeje T.O., Asogw A. Antidiarrhoeal activity of cashew (Anacardium occidentale) leaf extract enriched with zinc in wistar albino rats. SJBR, 2013, vol. 2, pp. 37-41.

12. David E.E., Yameen M.A., Igwenyi I.O., Okafor A.Ch., Obeten U.N., Obasi D.O., Ezeilo U.R., David Ch.N. The frequency of virulent genes and antimicrobial resistance patterns of diarrheagenic Escherichia coli isolated from stools of children presenting with diarrhea in a tertiary hospital in Abakaliki, Nigeria. Int. J. One Health, 2020, vol. 6, no. 2, pp. 147-152. doi: 10.14202/ IJOH.2020.147-152

13. Dumaru R., Baral R., Shrestha L.B. Study of biofilm formation and antibiotic resistance pattern of gram-negative bacilli among the clinical isolates at BPKIHS, Dharan. BMC Res. Notes, 2019, vol. 12, no. 1: 38. doi: 10.1186/s13104-019-4084-8

14. DuPont H.L., Steffen R. Use of antimicrobial agents for treatment and prevention of travellers' diarrhoea in the face of enhanced risk of transient fecal carriage of multi-drug resistant enterobacteriaceae: setting the stage for consensus recommendations. J. Travel Med., 2016, 23, no. 6: taw054. doi: 10.1093/jtm/taw054

15. Dutta S., Guin S., Ghosh S., Pazhani G.P., Rajendran K., Bhattacharya M.K., Takeda Y., Nair G.B., Ramamurthy T. Trends in the prevalence of diarrheagenic Escherichia coli among hospitalized diarrheal patients in Kolkata, India. PLoS One, 2013, vol. 8, no. 2: e56068. doi: 10.1371/journal.pone.0056068

16. Healey A., Furtado A., Cooper T., Henry R.J. Protocol: a simple method for extracting next-generation sequencing quality genomic DNA from recalcitrant plant species. Plant Methods, 2014, vol. 10: 21. doi: 10.1186/1746-4811-10-21

17. Ifeanyi C.I., Ikeneche N.F., Bassey B.E., Al-Gallas N., Ben Aissa R., Boudabous A. Diarrheagenic Escherichia coli pathotypes isolated from children with diarrhea in the Federal Capital Territory Abuja, Nigeria. J. Infect. Dev. Ctries., 2015, vol. 9, no. 2, pp. 165-174. doi: $10.3855 / j i d c .5528$

18. Levels and trends in child mortality: report 2020. URL: https://data.unicef.org/resources/levels-and-trends-in-child-mortality

19. Magiorakos A.P., Srinivasan A., Carey R.B., Carmeli Y., Falagas M.E., Giske C.G., Harbarth S., Hindler J.F., Kahlmeter G., Olsson-Liljequist B., Paterson D.L., Rice L.B., Stelling J., Struelens M.J., Vatopoulos A., Weber J.T., Monnet D.L. Multidrugresistant, extensively drug-resistant and pandrug-resistant bacteria: an international expert proposal for interim standard definitions for acquired resistance. Clin. Microbiol. Infect., 2012, vol. 18, no. 3, pp. 268-281. doi: 10.1111/j.1469-0691.2011.03570.x

20. Mah T.-F. Biofilm-specific antibiotic resistance. Future Microbiol., 2012, vol. 7, pp. 1061-1072. doi: 10.2217/fmb.12.76

21. Molecular characterization of enterotoxigenic Escherichia coli: effect on intestinal nitric oxide in diarrheal disease. J. Bacteriol. Parasitol., vol. 9: 339. doi:10.4172/2155-9597.1000339

22. Moyo S.J., Maselle S.Y., Matee M.I., Langeland N., Mylvaganam H. Identification of diarrheagenic Escherichia coli isolated from infants and children in Dar es Salaam, Tanzania. BMC Infect. Dis., 2007, vol. 7: 92. doi: 10.1186/1471-2334-7-92

23. Nguyen T.V., Le Van P., Le Huy C., Gia K.N., Weintraub A. Detection and characterization of diarrheagenic Escherichia coli from young children in Hanoi, Vietnam. J. Clin. Microbiol., 2005, vol. 43, no. 2, pp. 755-760. doi: 10.1128/JCM.43.2.755-760.2005

24. Nweze E.I. Aetiology of diarrhoea and virulence properties of diarrhoeagenic Escherichia coli among patients and healthy subjects in southeast Nigeria. J. Health Popul. Nutr., 2010, vol. 28, no. 3, pp. 245-252. doi: 10.3329/jhpn.v28i3.5551

25. Okeke I.N., Lamikanra A., Steinrück H., Kaper J.B. Characterization of Escherichia coli strains from cases of childhood diarrhea in provincial southwestern Nigeria. J. Clin. Microbiol., 2000, vol. 38, no. 1, pp. 7-12. doi: 10.1128/JCM.38.1.7-12.2000

26. Olorunshola I.D., Smith S.I., Coker A.O. Prevalence of EHEC O157:H7 in patients with diarrhoea in Lagos, Nigeria. APMIS, 2000, vol. 108, no. 11, pp. 761-763. doi: 10.1034/j.1600-0463.2000.d01-26.x

27. Onanuga A., Igbeneghu O., Lamikanra A. A study of the prevalence of diarrhoeagenic Escherichia coli in children from Gwagwalada, Federal Capital Territory, Nigeria. Pan. Afr. Med. J., 2014, vol. 17: 146. doi: 10.11604/pamj.2014.17.146.3369

28. Pavlickova S., Klancnik A., Dolezalova M., Mozina S.S., Holko I. Antibiotic resistance, virulence factors and biofilm formation ability in Escherichia coli strains isolated from chicken meat and wildlife in the Czech Republic. J. Environ. Sci. Health. B, 2017, vol. 52, no. 8, pp. 570-576. doi: 10.1080/03601234.2017.1318637

29. Porat N., Levy A., Fraser D., Deckelbaum R.J., Dagan R. Prevalence of intestinal infections caused by diarrheagenic Escherichia coli in Bedouin infants and young children in Southern Israel. Pediatr. Infect. Dis. J., 1998, vol. 17, no. 6, pp. 482-488. doi: 10.1097/00006454-199806000-00010

30. Protocol: a simple method for extracting next-generation sequencing quality genomic DNA from recalcitrant plant species. Plant Methods, 2014, vol. 10: 21. 
31. Rodas C., Mamani R., Blanco J., Blanco J.E., Wiklund G., Svennerholm A.M., Sjöling A., Iniguez V. Enterotoxins, colonization factors, serotypes and antimicrobial resistance of enterotoxigenic Escherichia coli (ETEC) strains isolated from hospitalized children with diarrhea in Bolivia. Braz. J. Infect. Dis., 2011, vol. 15, no. 2, pp. 132-137. doi: 10.1016/s1413-8670(11)70158-1

32. Sarowska J., Futoma-Koloch B., Jama-Kmiecik A., Frej-Madrzak M., Ksiazczyk M., Bugla-Ploskonska G., Choroszy-Krol I. Virulence factors, prevalence and potential transmission of extraintestinal pathogenic Escherichia coli isolated from different sources: recent reports. Gut Pathog., 2019, vol. 11: 10. doi: 10.1186/s13099-019-0290-0

33. Sharma D., Misba L., Khan A.U. Antibiotics versus biofilm: an emerging battleground in microbial communities. Antimicrob. Resist. Infect. Control, 2019, vol. 8: 76. doi: 10.1186/s13756-019-0533-3

34. Soleimani A., Foroozanfard F., Tamadon M.R. Evaluation of water and electrolytes disorders in severe acute diarrhea patients treated by WHO protocol in eight large hospitals in Tehran: a nephrology viewpoint. J. Renal. Inj. Prev., 2016, vol. 6, no. 2, pp. 109-112. doi: 10.15171/jrip.2017.21

35. Thakur S., Gray G.C. The Mandate for a Global "One Health" Approach to Antimicrobial Resistance Surveillance. Am. J. Trop. Med. Hyg., 2019, vol. 100, no. 2, pp. 227-228. doi: 10.4269/ajtmh.18-0973

36. Verma S., Venkatesh V., Kumar R., Kashyap S., Kumar M., Maurya A.K., Dhole T.N., Singh M. Etiological agents of diarrhea in hospitalized pediatric patients with special emphasis on diarrheagenic Escherichia coli in North India. J. Lab. Physicians, 2019, vol. 11, no. 1, pp. 68-74. doi: 10.4103/JLP.JLP_123_18

37. Vieira N., Bates S.J., Solberg O.D., Ponce K., Howsmon R., Cevallos W., Trueba G., Riley L., Eisenberg J.N. High prevalence of enteroinvasive Escherichia coli isolated in a remote region of northern coastal Ecuador. Am. J. Trop. Med. Hyg., 2007, vol. 76, no. 3, pp. 528-533.

\section{Авторы:}

Давид Э.Э., магистр биохимии, кафедра химии/биохимии Федеральныйого университета Алекса Эквуэме «Ндуфу Алик Икво», г. Икво, штат Эбони, Нигерия;

Ямин М.А., к.н. (фармакология антимикробных препаратов), кафедра аптечной службы, Университет COMSATS в Исламабаде, г. Абботтабад, Пакистан;

Игвэнйи И., к.н. (биохимия), доцент кафедры биохимии Государственного университета Эбони, штат Эбони, Нигерия;

Окафор А.С., к.н. (фармакология), кафедра микробиологии Университета Эдо, г. Иямхо, штат Эдо, Нигерия;

Обэтэн У.Н., магистр биохимии, кафедра химии/биохимии Федерального университета Алекса Эквуэме «Ндуфу Алик Икво", г. Икво, штат Эбони, Нигерия;

Обаси Д.О., магистр биохимии, кафедра химии/биохимии Федерального университета Алекса Эквуэме «Ндуфу Алик Икво», г. Икво, штат Эбони, Нигерия;

Эзэило У.Р., к.н. (энзимология), кафедра химии/биохимии Федерального университета Алекса Эквуэме «Ндуфу Алик Икво», г. Икво, штат Эбони, Нигерия;

Эмэриболэ М.Н., магистр биохимии, кафедра химии/биохимии Федерального университета Алекса Эквуэме «Ндуфу Алик Икво», г. Икво, штат Эбони, Нигерия;

Давид Ч.Н., магистр микробиологии, кафедра микробиологии Государственного университета Эбони, штат Эбони, Нигерия.

\section{Authors:}

David E.E., MSc (Biochemstry), Department of Chemistry/ Biochemistry, Alex Ekwueme Federal University Ndufu-Alike, Ikwo, Ebonyi State, Nigeria;

Yameen M.A., PhD (Microbial Pharmacology), Department of Pharmacy, COMSATS University Islamabad, Abbottabad Campus, Abbottabad, Pakistan;

Igwenyi I., PhD (Biochemistry), Associate Professor, Department of Biochemistry, Ebonyi State University, Ebonyi State, Nigeria; Okafor A.C., PhD (Microbiology), Department of Microbiology, Edo University, lyamho, Edo State, Nigeria;

Obeten U.N., MSc (Biochemstry), Department of Chemistry/ Biochemistry, Alex Ekwueme Federal University Ndufu-Alike, Ikwo, Ebonyi State, Nigeria;

Obasi D.O., MSc (Biochemstry), Department of Chemistry/ Biochemistry, Alex Ekwueme Federal University Ndufu-Alike, Ikwo, Ebonyi State, Nigeria;

Ezeilo U.R., PhD (Enzymology), Department of Chemistry/ Biochemistry, Alex Ekwueme Federal University Ndufu-Alike, Ikwo, Ebonyi State, Nigeria;

Emeribole M.N., MSc (Biochemstry), Department of Chemistry/ Biochemistry, Alex Ekwueme Federal University Ndufu-Alike, Ikwo, Ebonyi State, Nigeria;

David Ch.N., MSc (Biochemstry), Department of Microbiology, Ebonyi State University, Ebonyi State, Nigeria. 